\title{
Kepatuhan Pengendalian Intern dan Perilaku Etis Karyawan di PT. Intan Bali Cargo International
}

\author{
I Made Surya Widhi Wibawa 1 \\ Fakultas Ekonomi dan Bisnis \\ Universitas Udayana, Indonesia
}

\author{
I Ketut Suryanawa ${ }^{2}$ \\ Fakultas Ekonomi dan Bisnis \\ Universitas Udayana, Indonesia
}

\begin{abstract}
Surel: madesurya230699@gmail.com
ABSTRAK

PT. Intan Bali Cargo International merupakan sebuah perusahaan yang bergerak di bidang industri pengiriman barang internasional. Penelitian ini bertujuan untuk menganalisis pengaruh lingkungan pengendalian, penaksiran risiko, a ktivitas pengendalian, informasi dan komunikasi, serta pemantauan terhadap perilaku etis karyawan pada PT. Intan Bali Cargo International. Sampel ditentukan mengunakan metode purposive sampling sehingga terpilih sebanyak 47 responden sebagai sampel. Teknik analisis regresi linier berganda digunakan untuk menganalisis data. Hasil analisis menunjukan bahwa lingkungan pengendalian, penaksiran risiko, aktivitas pengendalian, informasi dan komunikasi, serta pemantauan berpengaruh positif dan siginifikan terhadap perilaku etis karyawan di PT. Intan Bali Cargo International. Hasil tersebut menunjukan bahwa semakin tinggi tingkat kepatuhan pengendalian intern maka perilaku etis karyawan di perusahaan tersebutjuga akan meningkat.
\end{abstract}

Kata Kunci: $\quad$ Lingkungan Pengendalian; Penaksiran Risiko; Aktivitas Pengendalian; Informasi Dan Komunikasi;Pemantauan.

\section{Internal Control Compliance and Ethical Behavior of Employees at PT. Intan Bali Cargo International}

\begin{abstract}
PT. Intan Bali Cargo International is a company engaged in the International freight forwarding industry. This studyaims to analyze the influence of the control environment, risk assessment, control activities, information $\mathcal{E}$ communication and monitoring to ethical behavior of employees at PT. Intan Bali Cargo International. The sample was determined using the purposive sampling method so that 47 respondents were selected as the sample. Multiple linear regression analysis technique was used to analyze the data. The results of the analysis show that the control environment, risk assessment, control activities, information and communication, and monitoring have a positive and significant effecton the ethical behavior of employees at PT. Intan Bali Cargo International. These results indicate that the higher the level of internal control compliance, the ethical behavior of employees in the company will also increase.
\end{abstract}

Keywords: Control Environment; Risk Assessment; Control Activities; Information and Communication; Monitoring.

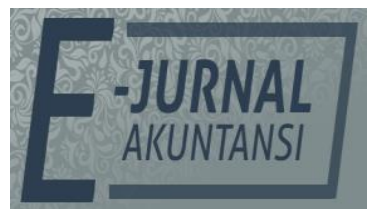

e-ISSN 2302-8556

Vol. 31 No. 12

Denpasar, Desember 2021

Hal. 3221-3230

DOI:

10.24843/EJA.2021.v31.i12.p14

PENGUTIPAN:

Wibawa, I. M. S. W. \&

Suryanawa, I. K. (2021).

Kepatuhan Pengendalian

Intern dan Perilaku Etis

Karyawan di PT. Intan Bali

Cargo International. E-Jurnal

Akuntansi, 31(12), 3221-3230

RIWAYAT ARTIKEL:

Artikel Masuk:

21 Juli 2021

Artikel Diterima:

23 September 2021

Artikel dapat diakses: https:/ / ojs.unud.ac.id/index.php/Akuntansi/index 


\section{PENDAHULUAN}

PT. Intan Bali Cargo International adalah sebuah perusahaan berlingkup International yang sudah didirikan sejak tahun 1973 sebagai industry pengiriman barang International. Setelah dilakukan observasi terdapat beberapa permasalahan yang terjadi pada perusahaan tersebut seperti, permasalahan dalam siklus penjualan dan penerimaan kas, permasalahan piutang pada pelanggan serta permasalahan pada gudang. Untuk meminimalisir permasalahan-permasalahan yang terjadi, setiap perusahaan umumnya menerapkan etika yang harus dipatuhi oleh para karyawannya (Wiryakriyana \& Widhiyani, 2017). Etika itu sendiri adalah regulasi atau aturan yang dibentuk manajemen, kesepakatan bersama dan pedoman untuk diterapkan dan dipatuhi semua anggota perusahaan/ organisasi tentang apa yang dinilai baik dan buruk dalam pelaksanaan dan pelayanan profesi (Kirana \& Wati, 2016). Etika dan perilaku etis merupakan prioritas yang sangat tinggi untuk perusahaan (Nugraha, 2015). Perilaku etis adalah sesuatu yang diterima secara moral sebagai baik dan benar sebagai lawan dari buruk atau salah dalam peraturan khususnya (Dinajayanti \& Rasmini, 2019). Perilaku etis sangat diperlukan dalam lingkungan perusahaan agar karyaw an maupun manajer dapat berkomunikasi secara efektif demi menciptakan lingkungan kerja yang baik (Manggu \& Nur, 2019). Dalam suatu perusahaan seringkali ada pihak yang tidak melaksanakan etika yang ditetapkan dengan berbagai alasan yang berpotensi merugikan perusahaan (Sidauruk \& Lestari, 2017). Perilaku tersebut dinamakan perilaku tidak etis. Tingginya perilaku tidak etis yang dilakukan oleh karyawan disebabkan oleh informasi yang diterima manajemen tidak akurat, tidak relevan, menjadi penghambat bagi para pembuat keputusan dalam mengambil kebijakan yang tepat bagi pencapaian tujuan perusahaan. Oleh karena itu, diperlukan adanya pengendalian intern untuk mengarahkan, mengawasi, dan mengukur sumber daya suatu organisasi (Wulandari, 2016).

Pengendalian ini berperan penting untuk mencegah dan mendeteksi kecurangan serta melindungi sumber daya organisasi, baik yang berwujud maupun tidak (Taradipa, 2017). Perilaku tidak etis dapat mengalami penurunan, jika adanya pengendalian intern mengenai kinerja sehingga tidak memungkinkan adanya peluang untuk melakukan kecurangan (Thoyibatun, 2012). Mengingat pentingnya masalah kepatuhan pengendalian intern terhadap perilaku etis karyawan, terdapat beberapa penelitian sebelumnya yang juga meneliti tentang perilaku etis karyawan. Hasil penelitian Fajariyanti (2016) menunjukkan bahwa secara simultan maupun parsial pengendalian intern, kepatuhan dan integritas manajemen berpengaruh secara signifikan terhadap perilaku etis karyawan. TRA menjelaskan hubungan antara sikap (attitude) dan perilaku (behavior) pada tindakan manusia dan dikembangkan oleh Azjen \& Fishbein (1980). Ini terutama digunakan untuk memprediksi bagaimana individu akan berperilaku berdasarkan sikap dan niat perilaku yang sudah ada sebelumnya. TRA menunjukkan bahwa niat yang lebih kuat mengarah pada peningkatan upaya untuk melakukan perilaku, yang juga meningkatkan kemungkinan perilaku tersebut dilakukan. Teori Perilaku Terencana atau TPB (Theory of Planned Behavior) merupakan pengembangan lebih lanjut dari Teori Perilaku Beralasan TRA (Theory of Reasoned Action). Seseorang dapat saja memiliki berbagai macam keyakinan terhadap suatu perilaku, namun ketika dihadapkan pada suatu kejadian tertentu, 
hanya sedikit dari keyakinan tersebut yang timbul untuk mempengaruhi perilaku. Sedikit keyakinan inilah yang menonjol dalam mempengaruhi perilaku individu (Ajzen,1991).

Selain itu menurut teori kepatuhan, kepatuhan dapat berarti bersifat patuh, ketaatan, tunduk, patuh pada ajaran atau aturan. Teori kepatuhan dapat mendorong individu untuk lebih mematuhi peraturan yang berlaku. Pengendalian intern terdiri dari lima indikator yaitu lingkungan pengendalian, penaksiran risiko, aktivitas pengendalian, informasi dan komunikasi, serta pemantauan (Hussaini \& Muhhamed, 2020). Lingkungan pengendalian merupakan dasar untuk semua komponen pengendalian intern, menyediakan disiplin dan struktur hal ini juga berpengaruh terhadap perilaku etis seorang karyawan (Rae et al., 2017). Hal ini dapat dilihat dari penelitian Mahadeen et al (2016), yang menunjukan bahwa lingkungan pengendalian berpengaruh positif terhadap perilaku etis. Penaksiran risiko yaitu identifikasi entitas dan analisis terhadap risiko yang relevan untuk mencapai tujuannya, membentuk suatu dasar untuk menentukan bagaimana risiko harus dikelola didalam menentukan kegiatan perlu juga melakukan penaksiran risiko (Rae et al., 2017). Hal ini ditunjukan oleh penelitian Mahadeen et al (2016) yang menunjukan bahwa aktivitas pengendalian berpengaruh positif terhadap perilaku etis. Kebijakan dan prosedur yang membantu menjamin bahwa arahan manajemen dilaksanakan adalah pengertian dari aktivitas pengendalian hal ini juga diperlukan untuk menentukan kinerja karyawan yang berperilaku secara etis (Rae et al., 2017). Hal ini didukung oleh penelitian dari penelitian Mahadeen et al (2016), yang menunjukan bahwa aktivitas pengendalian berpengaruh positif terhadap perilaku etis. Pengidentifikasian, penangkapan, dan pertukaran informasi dalam suatu bentuk dan waktu yang memungkinkan orang melaksanakan tanggung jawab mereka sangat menentukan didalam melaksanakan pekerjaan. Hal ini didukung oleh penelitian Mahadeen et al (2016), yang menunjukan bahwa informasi dan komunikasi berpengaruh positif terhadap perilaku etis. Pemantauan adalah proses yang menetukan kualitas kinerja pengendalian intern sepanjang waktu (Rae et al., 2017). Pemantauan sangat diperlukan didalam menetukan bagaimana karyawan melakukan pekerjaanya. Hal ini didukung oleh penelitian Mahadeen et al (2016), yang menunjukan bahwa pemantauan berpengaruh positif terhadap perilaku etis. Berdasarkan kajian teori yang telah dilakukan dan berdasar kepada hasil-hasil penelitian terdahulu, berikut rumusan hipotesis yang diajukan.

Beberapa penelitian mengenai pengaruh lingkungan pengendalian terhadap perilaku etis telah dilakukan sebelumnya. Hasil penelitian Fajariyanti (2015) menunjukan bahwa lingkungan pengendalian berpengaruh positif terhadap perilaku etis karyawan. Lingkungan pengendalian menetapkan corak suatu organisasi dan mempengaruhi kesadaran pengendalian orang-orangnya. Lingkungan pengendalian merupakan dasar semua komponen pengendalian intern, menyediakan disiplin dan struktur. Hasil penelitian Nugraha (2015) menunjukan bahwa Lingkungan Pengendalian berpengaruh positif pada perilaku etis karyawan. Begitu pula dengan hasil penelitian Kirana et al (2016) yang membuktikan adanya pengaruh Lingkungan Pengendalian pada perilaku etis karyawan. Hal ini berarti bahwa semakin meningkatnya lingkungan 
pengendalian maka perilaku etis juga akan semakin meningkat. Berdasarkan uraian tersebut, maka dapat dirumuskan hipotesis sebagai berikut.

$\mathrm{H}_{1}$ : Terdapat pengaruh lingkungan pengendalian terhadap perilaku etis karyawan.

Beberapa penelitian mengenai pengaruh penaksiran risiko terhadap perilaku etis telah dilakukan sebelumnya. Hasil penelitian Fajariyanti (2015) menunjukan bahwa penaksiran risiko berpengaruh positif terhadap perilaku etis karyawan. Penaksiran risiko adalah identifikasi entitas dan analisis terhadap risiko yang relevan untuk mencapai tujuannya, membentuk suatu dasar untuk menentukan bagaimana risiko harus dikelola. Hasil penelitian Nugraha (2015)menunjukan bahwa Penaksiran Risiko berpengaruh positif pada perilaku etis karyawan. Begitu pula dengan hasil penelitian Kirana et al (2016) yang membuktikan adanya pengaruh penaksiran risiko pada perilaku etis karyawan. Hal ini berarti bahwa semakin meningkatnya penaksiran risiko maka perilaku etis juga akan semakin meningkat. Berdasarkan uraian tersebut, maka dapat dirumuskan hipotesis sebagai berikut.

$\mathrm{H}_{2}$ : Terdapat pengaruh penaksiran risiko terhadap perilaku etis karyawan.

Beberapa penelitian mengenai pengaruh aktivitas pengendalian terhadap perilaku etis telah dilakukan sebelumnya. Hasil penelitian Fajariyanti (2015) menunjukan bahwa aktivitas pengendalian berpengaruh positif terhadap perilaku etis karyawan. Aktivitas pengendalian adalah kebijakan dan prosedur yang membantu menjamin bahwa arahan manajemen dilaksanakan. Hasil penelitian Nugraha (2015) menunjukan bahwa Aktivitas Pengendalian berpengaruh positif pada perilaku etis karyawan. Begitu pula dengan hasil penelitian Kirana et al (2016) yang membuktikan adanya pengaruh aktivitas pengendalian pada perilaku etis karyawan. Hal ini berarti bahwa semakin meningkatnya aktivitas pengendalian maka perilaku etis juga akan semakin meningkat. Berdasarkan uraian tersebut, maka dapat dirumuskan hipotesis sebagai berikut.

$\mathrm{H}_{3}$ : Terdapat pengaruh aktivitas pengendalian terhadap perilaku etis karyawan.

Beberapa penelitian mengenai pengaruh informasi dan komunikasi terhadap perilaku etis telah dilakukan sebelumnya. Hasil penelitian Fajariyanti (2015) menunjukan bahwa informasi dan komunikasi berpengaruh positif terhadap perilaku etis karyawan. Informasi dan komunikasi adalah pengidentifikasian, penangkapan, dan pertukaran informasi dalam suatu bentuk dan waktu yang memungkinkan orang melaksanakan tanggung jawab mereka. Hasil penelitian Nugraha (2015) menunjukan bahwa Informasi dan Komunikasi berpengaruh positif pada perilaku etis karyawan. Begitu pula dengan hasil penelitian Kirana et al (2016) yang membuktikan adanya pengaruh informasi dan komunikasi pada perilaku etis karyawan. Hal ini berarti bahwa semakin meningkatnya informasi dan komunikasi maka perilaku etis juga akan semakin meningkat. Berdasarkan uraian tersebut, maka dapat dirumuskan hipotesis sebagai berikut.

$\mathrm{H}_{4}$ : Terdapat pengaruh informasi dan komunikasi positif terhadap perilaku etis karyawan.

Beberapa penelitian mengenai pengaruh pemantauan terhadap perilaku etis telah dilakukan sebelumnya. Hasil penelitian Fajariyanti (2015) menunjukan bahwa pemantauan berpengaruh positif terhadap perilaku etis karyawan. 
Pemantauan adalah proses yang menentukan kualitas kinerja pengendalian intern sepanjang waktu. Hasil penelitian Nugraha (2015) menunjukan bahwa Pemantauan berpengaruh positif pada perilakuetis karyawan. Begitu pula dengan hasil penelitian Kirana et al (2016) yang membuktikan adanya pengaruh pemantauan pada perilaku etis karyawan. Hal ini berarti bahwa semakin meningkatnya pemantauan maka perilaku etis juga akan semakin meningkat. Berdasarkan uraian tersebut, maka dapat dirumuskan hipotesis sebagai berikut: $\mathrm{H}_{5}$ : Terdapat pengaruh positif pemantauan terhadap perilaku etis karyawan.

Hubungan antar variabel lingkungan pengendalian, penaksiran risiko, aktifitas pengendalian, informasi dan komunikasi, dan pemantauan terhadap perilaku etis dalam kerangka konseptual dapat terlihat pada Gambar 1.

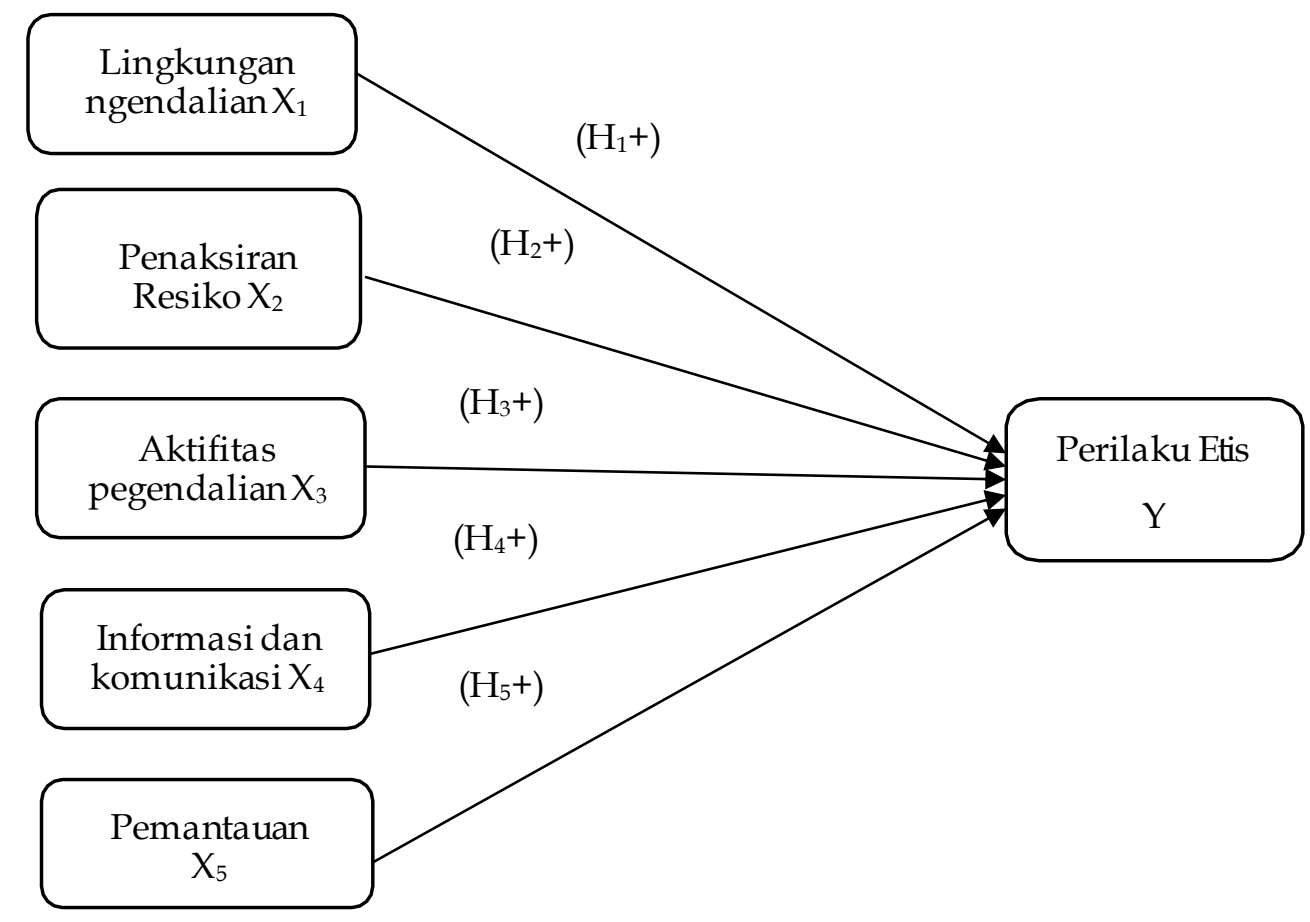

Sumber: Data Penelitian, 2021

Gambar 1. Kerangka Konseptual

\section{METODE PENELITIAN}

Penelitian ini menggunakan pendekatan kuantitatif yang berbentuk penelitian asosiatif, yaitu penelitian yang bertujuan untuk mengetahui hubungan atau pengaruh antara dua variabel atau lebih. Penelitian dilakukan di PT. Intan Bali Cargo International yang beralamat di Jl. Pulau Moyo No 100X, Pedungan Kecamatan Denpasar Selatan, Kota Denpasar, Bali. Obyek dalam penelitian ini yaitu perilaku etis karyawan pada PT Intan Bali Cargo International. Populasi penelitian berjumlah 55 karyawan. Sampel ditentukan dengan metode purposive sampling sehingga terpilih 47 responden sebagai sampel. Data diperoleh melalui kuesioner yang diukur dengan skala likert kemudian dilakukan uji instrument. Teknik analisis regresi linier berganda digunakan untuk menganalisis data. Adapun bentuk persamaan regresi dalam penelitian ini adalah $Y=\alpha+\beta_{1} X_{1}+\beta_{2} X_{2}+\beta_{3} X_{3}+\beta_{4} X_{4}+\beta_{5} X_{5}+\varepsilon$ 
WIBAWA, I. M. S. W. \& SURYANAWA, I. K.

HASIL DAN PEMBAHASAN

Tabel 1. Hasil Analisis Deskriptif

\begin{tabular}{lccccc}
\hline Variabel & $\mathrm{N}$ & Minimum & Maximum & Mean & $\begin{array}{c}\text { Std. } \\
\text { Deviation }\end{array}$ \\
\hline Lingkungan Pengendalian & 47 & 13,00 & 19,00 & 3,19148 & 1,36664 \\
Penaksiran Risiko & 47 & 12,00 & 20,00 & 3,24256 & 1,44367 \\
Aktivitas Pengendalian & 47 & 14,00 & 20,00 & 3,25532 & 1,15537 \\
Informasidan Komunikasi & 47 & 12,00 & 20,00 & 3,18724 & 1,64719 \\
Pemantauan & 47 & 19,00 & 19,00 & 3,20000 & 1,60163 \\
Perilaku Etis & 47 & 12,00 & 20,00 & 3,21276 & 1,89283 \\
\hline
\end{tabular}

Sumber: Data Penelitian, 2021

Berdasarkan Tabel 1, dapat diketahui bahwa hasil analisis deskriptif yang meliputi nilai mean, nilai minimum, nilai maksimum dan standar deviasi dari masing-masing variabel, dengan jumlah data yang diuji sebanyak 47 data. Misalkan variabel lingkungan pengendalian memiliki nilai minimum sebesar 13,00 dan nilai maksimum sebesar 19,00. Variabel lingkungan pengendalian yang diukur dengan 4 item pernyataan dengan bantuan skala likert 5 poin memiliki nilai rata-rata sebesar 3,19148. Nilai rata-rata 3,19148 menunjukkan bahwa respon dari responden dalam mengisi pernyataan kuesioner merasa kurang setuju pada masing-masing item pernyataan artinya lingkungan pengendalian cukup baik. Nilai standar deviasi variabel lingkungan pengendalian sebesar 1,36664. Hal ini berarti nilai standar deviasi lebih rendah dibandingkan dengan nilai rata-rata, yang artinya sebaran jawaban responden terkait dengan lingkungan pengendalian sudah merata. Begitu pula dengan penjelsan variabel lainnya. Hasil analisis regresi linier berganda disajikan pada Tabel 2 .

Tabel 2. Hasil Analisis Regresi Linier Berganda

\begin{tabular}{|c|c|c|c|c|c|}
\hline \multirow[t]{2}{*}{ Model } & \multicolumn{2}{|c|}{$\begin{array}{l}\text { Unstandardized } \\
\text { Coefficients }\end{array}$} & \multirow{2}{*}{$\begin{array}{l}\text { Standardized } \\
\text { Coefficients } \\
\text { Beta }\end{array}$} & \multirow[t]{2}{*}{$t$} & \multirow[t]{2}{*}{ Sig } \\
\hline & $\bar{B}$ & $\begin{array}{l}\text { Std. } \\
\text { Error }\end{array}$ & & & \\
\hline (Constant) & $-0,250$ & 1,626 & & $-0,154$ & 0,878 \\
\hline Lingkungan Pengendalian & 0,363 & 0,145 & 0,342 & 2,508 & 0,016 \\
\hline Penaksiran Risiko & 0,520 & 0,188 & 0,459 & 2,767 & 0,008 \\
\hline Aktivitas Pengendalian & 0,555 & 0,175 & 0,566 & 3,173 & 0,003 \\
\hline Informasi dan Komunikasi & 0,482 & 0,207 & 0,436 & 2,326 & 0,025 \\
\hline Pemantauan & 0,420 & 0,139 & 0,034 & 2,303 & 0,048 \\
\hline
\end{tabular}

Sumber: Data Penelitian, 2021

Berdasarkan Tabel 2, dapat dibentuk persamaan regresi dalam penelitian ini sebagai berikut.

$Y=-0,250+0,363 X_{1}+0,520 X_{2}+0,555 X_{3}+0,482 X_{4}+0,420 X_{5}$

Berdasarkan Tabel 2. Dapat diketahui bahwa nilai konstanta $(\alpha)$ sebesar 0,250. Hal ini berarti bahwa apabila penerapan lingkungan pengendalian, penaksiran risiko, aktivitas pengendalian, informasi dan komunikasi, dan pemantauan maka perilaku etis karyawan di PT. Intan Bali Cargo International akan menurun sebesar 0,250 satuan. Nilai koefisien regresi variabel lingkungan 
pengendalian $\left(\beta_{1}\right)$ sebesar 0,363 . Hal tersebut menunjukan apabila variabel lingkungan pengendalian naik satu satuan maka variabel perilaku etis akan meningkat sebesar 0,363 satuan dengan asumsi variabel lain dianggap konstan.

Hasil menunjukan bahwa semakin baik penerapan lingkungan pengendalian pada karyawan maka semakin meningkat perilaku etis karyawan di PT. Intan Bali Cargo International. Hasil ini sejalan dengan hasil penelitian sebelumnya yang dilakukan oleh Fajariyanti (2016) dan Mahadeen et al (2016) yang membuktikan adanya pengaruh lingkungan pengendalian pada perilaku etis karyawan. Hasil penelitian ini tidak sejalan dengan penelitian Tewal (2015) yang menyatakan bahwa lingkungan pengendalian tidak berpengaruh terhadap perilaku etis karyawan. Hasil penelitian ini menunjukkan bahwa dengan menerapkan lingkungan pengendalian dapat meningkatkan perilaku etis karyawan. Hal ini dapat dilihat dari berbagai struktur, yang pertama yaitu lingkungan pengendalian. Pemberian wewenang dan tanggungjawab masing-masing bagian sudah jelas digambarkan.

Hasil menunjukan bahwa semakin baik penerapan penaksiran risiko pada karyawan maka semakin meningkat perilaku etis karyawan di PT. Intan Bali Cargo International. Hasil ini sejalan dengan hasil penelitian sebelumnya yang dilakukan oleh Fajariyanti (2016) dan Mahadeen et al (2016) yang membuktikan adanya pengaruh penaksiran risiko pada perilaku etis karyawan. Hasil penelitian ini tidak sejalan dengan penelitian Findiani (2015) yang menyatakan bahwa penaksiran risiko tidak berpengaruh terhadap perilaku etis karyawan. Struktur pengendalian intern yang kedua yaitu penaksiran risiko yang dapat mempertimbangkan kemungkinan transaksi yang telah dicatat atau mengidentifikasi dan menganalisis estimasi signifikan yang dicatat dalam laporan keuangan. Dengan adanya penaksiran risiko tersebut, maka risiko yang relevan dengan pelaporan keuangan mencakup peristiwa dan keadaan intern yang terjadi dan secara negatif mempengaruhi kemampuan entitas untuk mencatat, mengolah, meringkas dan melaporkan data keuangan secara konsisten.

Hasil menunjukan bahwa semakin baik penerapan aktivitas pengendalian pada karyawan maka semakin meningkat perilaku etis karyawan di PT. Intan Bali Cargo International. Hasil ini sejalan dengan hasil penelitian sebelumnya yang dilakukan oleh Fajariyanti (2016) dan Mahadeen et al (2016) yang membuktikan adanya pengaruh aktivitas pengendalian pada perilaku etis karyawan. Hasil penelitian ini tidak sejalan dengan penelitian Prayogi (2016) yang menyatakan bahwa aktivitas pengendalian tidak berpengaruh terhadap perilaku etis karyawan. Pada struktur pengendalian yang ketiga yaitu aktivitas pengendalian dalam melaksanakan kegiatan fungsi pengiriman. Perusahaan telah memenuhi unsur struktur pengendalian intern yang ketiga. Perusahaan sudah memiliki kinerja yang baik, hal ini bisa dilihat dari kemampuan mereka menghasilkan laporan keuangan yang cukup diandalkan dan aktivitas perusahaan yang terus berlangsung. Pengolahan informasi dilakukan dengan menggunakan komputer sehingga lebih cepat dan akurat.

Hasil menunjukan bahwa semakin baik penerapan informasi dan komunikasi pada karyawan maka semakin meningkat perilaku etis karyawan di PT. Intan Bali Cargo International. Hasil ini sejalan dengan hasil penelitian 
sebelumnya yang dilakukan oleh Fajariyanti (2016) dan Mahadeen et al (2016) yang membuktikan adanya pengaruh informasi dan komunikasi pada perilaku etis karyawan. Hasil penelitian ini tidak sejalan dengan penelitian Sintyadevi (2015) yang menyatakan bahwa informasi dan komunikasi tidak berpengaruh terhadap perilaku etis karyawan. Struktur pengendalian intern informasi dan komunikasi yaitu transaksi diolah secara manual dan komputer. Transaksi dimulai pada saat diterima order, selanjutnya masing-masing bagian melaksanakan tugasnya secara terpisah. Pada saat pembagian tugas transaksi tersebut dikendalikan dengan sistem otorisasi sesuai dengan wewenang kepala bagian.

Hasil menunjukan bahwa semakin baik penerapan pemantauan pada karyawan maka semakin meningkat perilaku etis karyawan di PT. Intan Bali Cargo International. Hasil ini sejalan dengan hasil penelitian sebelumnya yang dilakukan oleh Fajariyanti (2016) dan Mahadeen et al (2016) yang membuktikan adanya pengaruh pemantauan pada perilaku etis karyawan. Hasil penelitian ini tidak sejalan dengan penelitian Sidauruk (2017) yang menyatakan bahwa pemantauan tidak berpengaruh terhadap perilaku etis karyawan. Struktur pengendalian intern pemantauan ini mencakup kebijakan pengendalian untuk masing-masing kegiatan dan memverifikasi kualitas pengendalian fungsi pengiriman. Proses ini dilaksanakan melalui kegiatan yang berlangsung secara terus menerus dan evaluasi secara terpisah.

\section{SIMPULAN}

Simpulan yang dapat ditarik berdasarkan hasil dan pembahasan yang sudah dijelaskan sebelumnya yaitu, Lingkungan Pengendalian berpengaruh positif pada perilaku etis karyawan di PT. Intan Bali Cargo International. tersebut. Penaksiran Risiko berpengaruh positif pada perilaku etis karyawan di PT. Intan Bali Cargo International. Aktivitas Pengendalian berpengaruh positif pada perilaku etis karyawan di PT. Intan Bali Cargo International. Informasi dan Komunikasi berpengaruh positif pada perilaku etis karyawan di PT. Intan Bali Cargo International. Pemantauan berpengaruh positif pada perilaku etis karyawan di PT. Intan Bali Cargo International. Keterbatasan penelitian ini adalah pada jumlah sampel yang terbatas yaitu 47 responden. Maka dari itu disarankan kepada peneliti selanjutnya agar menambah jumlah responden penelitian, sehingga diperoleh data dan hasil yang lebih baik.

\section{REFERENSI}

Amalia, F. A. (2015). Audit Quality: Does Time Pressure Influence Independence and Audit Procedure Compliance of Auditor . JAI (Journal of Accounting and Investment) vol. 20 no. 1.

Akhmetshin, E. M., Vasilev, V. L., Bakhvalov, S. I. Prikhodko, a. n., \& Kazakov, A. V. (2017). Internal Control in The System of Innovation Management In The Modern Business Environment. International Journal of Economic Research, 14(15), pp. 409-416.

Akhmetshin, E. M., Vasilev, V. L., Vlasova, N. I., Kazakov, A. V., Kotova, X. Y., \& Ilyasov, R. H. (2019). Improving management functions at an enterprise: Levels of the internal control system. Quality - Access to Success, 20(171), 39- 
43.

Bharaditya, I. W. P., Sukarsa, I. M., \& Wirabuana, P. (2017). Internal Control Improvement for Creating Good Governance. International Journal of Information Engineering and Electronic Business, 9(3), 9-17. https:// doi.org/10.5815/ijieeb.2017.03.02

Buckley, M. R., D. S. Wiese M. G. and Harvey, (2014). An Investigation into Dimensions of Unethical Behavior. Journal of Education for Bussiness 73.

Chiarini, A. (2017) Risk-Based Thinking According to ISO 90012015 Standard and The Risk Sources European Manufacturing SMEs Intend to manage.TQM Journal,29(2), 310-323. 10.1108/TQM-04-2016-0038

Dinajayanti, N. W. A. D., \& Rasmini, N. K. (2019). Pengendalian intern, loyalitas dan integritas manajemen pada perilaku etis karyawan PT.Orindo alam ayu Denpasar. E-Jurnal Akuntansi Universitas Udayana, 17, 338-363.

Fajariyanti, D. (2016). Pengaruh Kepatuah Pengendalian Intern Terhadap Perilaku Etis Karyawan Dalam Sistem Penggajian (Studi Kasus pada Karyawan Water Park Gumul Paradise Island. Jurnal Akuntansi Dan Ekonomi, 1(4). http:/ / weekly.cnbnews.com/news/article.html?no=124000

Frazer, L. (2016). Internal Control: Is it a Benefit or Fad to Small Companies? A Literature D...: Search Everything at Mercyhurst University. Journal of Accounting \& Finance, 16(4), 2016.

Goloshchapova, L. V., Smolentsev, V. M., Korelskiy, D. S., Rudenko, M. N., \& Sergodeeva, E. A. (2017). Theoretical And Methodological Basis Of Organization Of The Internal Control System Of The Industrial Enterprise. International Journal of Applied Business and Economic Research, 15(12), 261-271.

Hussaini, U., \& Muhhamed, U. (2020). The effect of internal control on the performance of pharmaceutical firms in vietnam. International Journal of Management Research E Review, 7(2), 395-400. https:/ / doi.org/10.5267/j.ac.2020.11.012

Kirana, C. G., \& Wati, A. (2016). Jurnal Ilmiah Akuntansi dan Ekonomi Volume .1. No. 1 Maret 2016 95. Jurnal Ilmiah Akuntansi Dan Ekonomi, 1(1), 95-106. https:/ / www.usni.ac.id/lppm/jurnal/6. P HERISTON (95-106).pdf

Kodolova, I. A., Yusupova, L. M., Nikonova, T. V., Khisamova, E. D. Hasbiullina, G. M., \& Solodkova, I. M. (2017). The Dinamic of Innovative Activity Development: The Enterprises of Tatarstan. Astra Salvensis, Supplement No.2/2017, pp.415-428

Lunenburg, F. C. (2012). Compliance Theory and Organizational Effectiveness. Internationel Ajaournal Of Scholarly Academic Intellectual Diversity, 4(1).

Mahadeen, B., Al-Dmour, R. H., Obeidat, B. Y., \& Tarhini, A. (2016). Examining the Effect of the Organization's Internal Control System on Organizational Effectiveness: A Jordanian Empirical Study. International Journal of Business Administration, 7(6). https:/ / doi.org/10.5430/ijba.v7n6p22

Manggu, S. A. R., \& Nur, N. S. (2019). Pengaruh Pengendalian Internal Terhadap Perilaku Etis Karyawan Dalam Sistem Penggajian. Journal of Economic, Public, and Accounting (JEPA), 1(2), 113-122.

Nugraha, W. (2015). Kompensasi Manajemen Terhadap Perilaku Etis Pegawai ( Studi Kasus Dinas Pendapatan, Pengelolaan Keuangan Dan Aset Daerah Wonogiri ). Jurnal Riset Akuntansi, 3(1). 
Rae, K., Sands, J., \& Subramaniam, N. (2017). Associations among the Five Components within COSO Internal Control-Integrated Framework as the Underpinning of Quality Corporate Governance. Australasian Accounting, Business and Finance Journal, 11(1), 28-54. https:/ / doi.org/10.14453/aabfj.v11i1.4

Rahim, S. A. A., Nawawi, A., \& Salin, A. S. A. P. (2017). Internal Control Weaknessiss in a Cooperativebody: Malaysian Experience. International Journal of Management Practice, 10(2), 131-151. 10.1504/IJMP.2017.083082

Sidauruk, T. D., \& Lestari, S. (2017). Pengaruh Pengendalian Intern, Kepatuhan, Kompensasi Manajemen Terhadap Perilaku Etis Karyawan (Studi Kasus: Pada Perusahaan Distributor Farmasi Pt Enseval Putera Megatrading Tbk Pusat). Jurnal Ilmiah Akuntansi Dan Ekonomi, 1(2), 16-26.

Sozinova, A.A., Zhelnina, E.V., Prokhorova, V.V., Zelinskaya, M.V., \& Putilina, I.N. (2016). Economic environment activities of russian corporations. International Journal of Economics and Financial Issues, 6(1S), 52-56.

Taradipa, P. S. (2017). Pengaruh Pengendalian Intern Terhadap Kinerja Karyawan studi kasus pada PT.Bank Panin Tbk cabang Kendari. Jurnal Akuntansi, 1(1), 2-13.

Thoyibatun, S. (2012). Faktor-Faktor Yang Berpengaruh Terhadap Perilaku Tidak Etis Dan Kecenderungan Kecurangan Akuntansi Serta Akibatnya Terhadap Kinerja Organisasi. EKUITAS (Jurnal Ekonomi Dan Keuangan), 16(2), 245. https:/ / doi.org/10.24034/j25485024.y2012.v16.i2.2324

Wiryakriyana, A. . G., \& Widhiyani, N. L. S. (2017). Pengaruh Ukuran Perusahaan, Leverage, Auditor Switching, Dan Sistem Pengendalian Internal Pada Audit Delay. E-Jurnal Akuntansi, 2017(1), 771-798.

Wulandari, E. (2016). Pengaruh Sistem Pengendalian Intern Dan Koompensasi Terhadap Perilaku Etis Karyawan Pada PT.Pegadaian (PERSERO) Cabang Syariah Palembang. Journal Islamic Economics, 53(9), 1689-1699. 